ing. The postgraduate centre should have between 70 and 100 journals and very few textbooks. There should also be rooms for research. Mr. E. H. Cornelius (Assistant Librarian, Royal College of Surgeons) said that no one quite knew what kind of library a medical centre should have. It was not always appreciated that a great deal of outside help was available from expert bodies. For example public libraries had set up a system of inter-regional lending, by which each region made itself responsible for provision of books on one or more specialized subjects. The National Lending Library for Science and Technology at Boston Spa was aiming to cover the 26,000 journals currently published, and borrowing by hospitals was possible. The medical section of the Library Association provided a duplicating service as well as lists of periodicals for exchange.

Dr. O. Plunket (Chertsey) described some of the ingenious techniques he had used, with advice from the Wellcome Foundation, in setting up a museum in his centre. There were many ways of providing a "visual revision course," which could be changed frequently and did not need much money or space. It was a way of attracting people to the centre. Dr. D. Matringly (Exeter) discussed journal clubs, the great advantage of which was that all members took an active part. They should be small, departmental, and limited to senior house officers and above. It was always difficult to find a suitable time but important to establish the habit. Dr. B. LENNOX (Glasgow) defined interdepartmental teaching as a dialogue between a minimum of two people each of whom was interested in what the other had to say. He did not like the panel discussion, which tended to be like a relay with only the smallest amount of communication. He preferred to put up an object to be kicked around. Clinical meetings and clinicopathological conferences were most important events, at which consultants must be prepared to speak freely and put forward ideas for the enjoyment of their colleagues.

\section{Organization and Finance}

Professor G. A. SMarT (Newcastle upon Tyne) said that some form of national coordination of postgraduate centres was a matter of urgency. It was doubtful if the universities or Royal Colleges would undertake this, and he thought that the Ministry of Health might be responsible for provision and maintenance, while an outside body like A.S.M.E. might co-ordinate activities and the interchange of ideas. Dr. A. A. G. LEwIS said that his experience as adviser to the S.E. Metropolitan Region was that a regional postgraduate committee representing all interests was the best method of co-ordination. Dr. A. J. MCCall (Stoke-on-Trent) pointed out that maintenance, secretarial work, and finance were the big problems at a local level, especially where, as in his case, the centre was not associated with a hospital management committee. Mr. D. C. BowIE (London) in discussion suggested that the universities might take a greater part, and one way would be to appoint clinical professors in each region for a trial period of five years.

Dr. S. R. F. WhitTAKer (Warwick) did not think that finance was as great a problem as finding time for people to do postgraduate teaching. $\mathrm{He}$ estimated that a wide variety of schemes financed by the Birningham Regional Hospital Board cost something in excess of $£ 100,000$ out of a total budget of $£ 50 \mathrm{~m}$. Nevertheless, money had come from other sources, especially in the building of centres, a point taken up by Dr. J. LISTER (Windsor), who described the way in which money had been raised, mostly from donations, for his centre. Several speakers stressed the difficulty of meeting running costs, and Mr. P. S. BOULTÉR (Guildford) asked whether it might be possible to obtain grants from the education authorities. But it seemed clear from Dr. WHITTAKER's analysis that money could be made available from the health service and was not likely to involve a large sum, since many centres had already been built.

It is hoped to publish the proceedings in the Postgraduate Medical fournal.

\title{
Roehampton 1915-1965
}

\author{
ST. J. D. BUXTON,* F.R.C.S.
}

The prosthetic centre at Roehampton was founded 50 years ago, largely owing to the efforts of Mrs. M. E. Gwynne Holford, who appreciated the need to help those who lost a limb in the first world war. She urged a group of influential people to make public the necessity for adequate arrangements for the provision of artificial limbs. A trust was founded to provide for the treatment of sailors, soldiers, and airmen who had lost their legs in the war. This was originally known as the Trust of Queen Mary's Convalescent Auxiliary Hospital and became regulated by the Charity Commissioners. Subsequent to the loan of Roehampton House by Mr. Wilson and its being commandeered by the War Office the governors of the Trust acquired Roehampton estate, which included the mansion and 25 acres. On 25 June 1915 the Convalescent Auxiliary Hospital, then providing 25 beds, was officially opened.

In May 1916 The Times reported that " the atmosphere [of Queen Mary's Hospital at Roehampton] is just what it should be, active and benevolent, and the public may rest assured that the victims of the war are receiving all the help that ingenuity can devise." The demand for accommodation increased to such an extent that 900 beds were available in 1918. During the war, of the 40,000 who lost their limbs, 26,000 went to Roehampton for the supply of the first and, in many cases, the second artificial limb.

- Consulting Orthopaedic Surgeon to King's College Hospital, London.
Before the closure of the Special Surgical Hospital for Service men at Shepherd's Bush and the Queen's Hospital, for facial injuries, at Sidcup, the remaining patients were transferred to Roehampton. At this time the Minister of Pensions leased the hospital and limb-fitting centre from the Trust at a peppercorn rent and administered both. Premises were made available for limb-makers, who rented the property and factories from the Governors of the Trust. On 6 May 1925 Queen Mary opened an extension to the hospital of permanent buildings. By 1936 the Governors of the Trust, after obtaining the consent of the Charity Commissioners and making an arrangement with the Minister of Pensions, provided limb-fitting services for civilians, particularly railwaymen and miners, who, they considered, had limited facilities after loss of limb. By this time Roehampton had become the national centre for the provision of artificial limbs and for the training of doctors as surgeons to fit them ; in addition, 20 smaller centres administered from there had been placed in the large towns and counties.

During and after the second world war it was inevitable that amputees would reach Roehampton, though fortunately the Service men who had received wounds necessitating amputation were fewer than those in the 1914-18 war. The centre was organized to meet the demand of the Services. Wards were allocated for those requiring specialist investigation and treatment for tropical diseases, such as had been acquired in the Far East, mostly among prisoners of war. 


\section{Present Organization}

The Trust still owns the Roehampton estate and has an income from factory rentals, invested funds, and donations. The hospital, now providing 400 beds, is leased at a peppercorn rent to the Minister of Health until 2002, and the Minister has appointed the Board of Governors of Westminster Hospital to manage it. The Minister, however, does administer the limbfitting centre, which is leased to him at a beneficial rent, and the satellite centres. In 1961 the Governors of the Trust changed their title to Trustees and are not concerned with National Health Service patients in the hospital. No wards or beds are set aside for disabled ex-Service men, but the Minister has agreed with the Trust that they have preferential admission, excepting those with pulmonary tuberculosis or impaired mental health, who are treated elsewhere. Westminster Hospital is responsible for the hospital welfare of the National Health Service patients and the majority of ex-Service men and appoints medical and lay staff to the hospital but not to the limb-fitting centre. It is noticeable that there is grouping in the hospital for the Service men requiring plastic surgery, operations in connexion with loss of limb, and investigation of tropical disease.

The majority of the amputations in the United Kingdom are carried out by general surgeons in the hospitals where they normally work. Orthopaedic surgeons do many of the emergency amputations required owing to accident. A small number of patients are sent to Roehampton for decision and amputation, if necessary, and the majority of secondary operations, when required before limb-fitting, are performed there.

The limb-fitting centre has become more of a national centre than ever. Of the 3,500 new amputees who attend each year $70 \%$ have lost a limb from disease of blood-vessels and $25 \%$ from accidents.

The Trust, under the chairmanship of Sir Arton Wilson, shows appreciation of the changes necessary for the adequate provision of artificial limbs for both civilian and Service casualties. Not only has it spent $£ 100,000$ on the limb-fitting centre and the factories but it is contributing $£ 63,000$ to a research and works building, a project in which the Ministry of Health and the Trust are co-operating. This is required for the constant study of design and materials used in artificial limbs, including such advances as powered limbs. The research committee, under the chairmanship of Mr. H. Jackson Burrows, considers any project submitted that may benefit the amputee. The research workers are assisted by the committee in the planning and financial aspects of their work and have the advantage of criticism by specialist members.

It is the high standard of the routine work that has given Roehampton its good name. Without doubt, credit for the original medical arrangements should go to Muirhead Little (1854-1935). He was an experienced orthopaedic surgeon, who set a pattern when Roehampton was first opened both for the technique of amputation and for the standard prostheses. $\mathrm{He}$ was helpful to the amputee of the first world war and his influence was appreciated for many years. Following his example, the staff educate the amputee in the use and care of the artificial limb; stress is laid on the necessity of wearing a stump sock and on its method of application. There is a walking school in which the amputee learns to walk, sit, and go up and down steps. The original pattern of education has been improved year by year. Active rehabilitation has replaced a somewhat leisurely and inactive convalescence, which followed all surgical procedures in the Edwardian and Georgian eras. Physical and mental confidence are restored, and the man or woman is prepared for return to profitable employment. Even so, it is surprising how a double amputee will often teach himself to be mobile, and many enjoy physical recreation, such as swimming, golf, and tennis.

The national limb-fitting service has acquired an international reputation and is visited by doctors from many parts of the world. Technicians, particularly from Europe, receive training in the factories, which remain private undertakings in contract with the Ministry of Health.

The author wishes to express his appreciation for some of the historical information to the Trustees and the Clerk to the Trustees.

\title{
Indications for Laboratory Tests for Toxoplasmosis
}

\author{
D. G. FLECK,* M.D., M.C.PATH., DIP.BACT.; G. B. LUDLAM, $†$ M.D., F.C.PATH., D.T.M.\&H., D.L.o.
}

Brit. med. F., 1965, 2, 1239-1240

Our experience in carrying out the routine testing of sera for toxoplasma antibody has been that there is often uncertainty about when to ask for special tests for the diagnosis of toxoplasmosis. Sera are not uncommonly sent in when there seems to be no real need for testing; on the other hand, it is probable that more testing of sera in certain types of case is indicated. It is proposed, therefore, to provide here a tentative guide on the indications for laboratory tests for toxoplasmosis.

\section{Tests for Toxoplasma Antibody}

The cytoplasm-modifying test of Sabin-Feldman (dye-test) is the one routinely used in this country. It is a sensitive test which shows the presence of antibody in about $30-40 \%$ of the normal adult population. The most convincing method of diagnosing active toxoplasmosis is by the demonstration of at least a fourfold rise in titre. However, in practice, by the time the first serum is obtained the titre has usually already reached a high level, and we tend therefore to attach a probable diagnostic significance to titres of $1 / 512$ or over. Nevertheless, on rare occasions titres in excess of this figure may be found in healthy persons with no history of recent illness.

\section{Indications for Serological Testing}

The following are the main conditions in which toxoplasmosis may be suspected, and in which antibody tests preferably of acute and convalescent sera may be necessary.

\section{Lymphadenopathies}

(a) Cases of apparent glandular fever, where the Paul-Bunnell test and bacteriological tests are negative. 